\title{
Upaya Meningkatkan Kemampuan Berpikir Kritis Siswa Kelas X Melalui Pembelajran Kooperatif Tipe Numbered Head Together
}

\author{
Khairani $^{1)}$, Zul Amry ${ }^{2)}$, Roslinawati Harahap ${ }^{3)}$ \\ ${ }^{1)}$ Dosen Jurusan Matematika, Universitas Negeri Padang \\ ${ }^{2)}$ Dosen Jurusan Matematika, Universitas Negeri Medan \\ ${ }^{3)}$ Guru Matematika MAN Model 2 Medan \\ khairani@fmipa.unp.ac.id
}

\begin{abstract}
Critical thinking is reasonable reflective thinking focused on deciding what to believe or do. The upper three levels of Bloom's taxonomy of educational objectives (analysis, synthesis, and evaluation) are part of critical thinking. Purpose of this research was to improve critical thinking of tenth grade secondary students through Cooperative Learning Number Head Together (NHT). Type of this research was classroom action research. Subjects were 40 students of class X-6 MAN 2 Model Medan in year academic 2013/2014. This research had two cycles with three strategies to collecting data: experiencing, enquiring and examining. Researcher reflected students' critical thinking through observation, test, interviews, and students' records, before Cooperative Learning Numbered Head Together (NHT) is adopted in classroom. Data analysis was done by quantitative and qualitative approach. Based on data analysis, it shows that students' critical thinking are increase from score percentage $32,42 \%$ at low level (before cyclus I) to $49,13 \%$ at medium level (after cyclus I) and $55,63 \%$ at medium level (after cyslus II). It can be concluded that students' critical thinking can be improved by implementing cooperative learning numbered head together in the classroom.
\end{abstract}

Keywords : classroom action research, cooperative learning numbered head together, critical thinking

his is an open access article distributed under the Creative Commons 4.0 Attribution License, which permits unrestricted use, distribution, and reproduction in any medium, provided the original work is properly cited $@ 2018$ by author and Universitas Negeri Padang.

\section{PENDAHULUAN}

Pendidikan Indonesia merupakan "pabrik" penghasil sumber daya manusia yang nantinya akan mengelola sumber daya alam Indonesia yang kaya dan melimpah. Sebagai mana Undang-Undang Pendidikan Nasional nomor 20 tahun 2003 bab I pasal 1 dan ayat 1 yang menyatakan bahwa pendidikan adalah usaha sadar dan terencana untuk mewujudkan suasana belajar dan proses pembelajaran agar peserta didik secara aktif mengembangkan potensi dirinya untuk memiliki kekuatan spritual keagamaan, pengendalian diri, kepribadian, kecerdasan, akhlak mulia, serta keterampilan yang diperlukan dirinya, masyarakat, bangsa dan negara.

Salah satu bidang studi yang memiliki peranan penting dalam pendidikan adalah mate matika. Matematika merupakan salah satu ilmu pengetahuan yang tujuan pengajarannya adalah agar siswa mampu menguasai konsep-konsep dan mengkaitkan antarkonsep serta mampu menggunakan konsep-konsep itu dalam metode ilmiah untuk memecahkan masalah dalam kehidupan sehari-hari. Hudojo (1988) menyata kan bahwa matematika adalah ilmu yang berkenaan dengan ide-ide abstrak yang tersusun secara hirarkis dengan penalaran deduktif. Berdasarkan Garis-Garis Besar Program Pengajaran matematika, tujuan umum diberikannya matematika pada jenjang pendidikan dasar dan menengah meliputi dua hal, yaitu: (1) menyiapkan siswa agar sanggup menghadapi perubahan keadaaan di dalam kehidupan dan di dunia yang selalu berkembang, melalui latihan bertindak atas dasar pemikiran secara logis, rasional, kritis, cermat, jujur, efektif dan efisien; (2) menyiapkan siswa agar dapat menggunakan matematika dan pola pikir matematika dalam kehidupan sehari-hari dan dalam mempelajari berbagai ilmu pengetahuan. Terlihat bahwa salah satu hal penting dari tujuan pembelajaran matematika tersebut adalah kemampuan berpikir kritis (Suherman, 2001).

Ennis (1993) berpendapat bahwa berpikir kritis merupakan suatu proses penggunaan kemampuan berpikir secara efektif yang dapat membantu seseorang untuk membuat, meng evaluasi serta mengambil keputusan tentang apa yang diyakini atau dilakukan. Sedangkan Eggen dan Kauchak (2012) menyatakan bahwa berpikir 
kritis adalah kemampuan dan kecenderungan seseorang untuk membuat dan melakukan asesmen terhadap kesimpulan berdasarkan bukti. Pendapat itu juga didukung oleh Jhon W Santrack (2008) yang menyatakan bahwa berpikir kritis adalah pemikiran efektif dan produktif serta melibatkan evaluasi bukti. Beberapa cara yang dapat digunakan guru untuk memasukkan pemikiran kritis dalam proses pembelajaran, antara lain adalah : (1) Jangan hanya bertanya tentang "apa" yang terjadi, tetapi tanyakan juga "bagaimana" dan "mengapa"; (2) Kaji dugaan "fakta" untuk mengetahui apakah ada bukti yang mendukung; (3) Berdebatlah secara rasional bukan emosional; (4) Akui bahwa terkadang ada lebih dari satu jawaban atau penjelasan yang baik; (5) Bandingkan berbagai jawaban untuk menjawab pertanyaan dan nilailah mana jawaban yang benar-benar terbaik; (6) Evaluasi dan kalau mungkin tanyakan apa yang dikatakan orang lain bukan sekedar menerima begitu saja jawaban sebagai kebenaran; (7) Ajukan pertanyaan dan pikirkan di luar apa yang sudah kita tahu untuk menciptakan ide baru dan informasi baru. Berdasarkan uraian tersebut, dapat disimpulkan bahwa kemampuan berpikir kritis adalah kemampuan berpikir secara efektif yang dapat membantu seseorang untuk membuat, meng evaluasi serta mengambil keputusan tentang apa yang diyakini atau dilakukan.

Terdapat beberapa ahli yang mengungkapkan indikator berpikir kritis. Adapun Ennis (1993) menyatakan bahwa orang yang memiliki kemampuan berpikir kritis dapat dilihat dari indikator sebagai berikut : (1) Menilai kredibilitas sumber (judge the credibility of sources); (2) Mengidentifikasi alasan dan asumsi (identify reasons and assumptions); (3) Menilai kualitas dari sebuah argumen termasuk diterima tidaknya alasan, asumsi dan buktinya (judge the quality of an argument, including the acceptability of its reasons, assumptions, and evidence); (4) Mengembangkan dan mempertahankan posisi terhadap sebuah isu (develop and defend a position on an issue); (5) Mempertanyakan ketepatan pengklarifikasian pertanyaan (ask appropriate clarifying questions); (6) Merencanakan percobaan dan menilai rancangan percobaan (plan experiments and judge experimental designs) ; (7) Mendefinisikan waktu dalam cara yang tepat untuk konteks (define term in a way appropriate for the context); (8) Berpikir terbuka (be open-minded); (9) Mencoba untuk mudah diinformasikan (try to be well informed); dan (10) Menggambarkan kesimpulan ketika dibutuhkan tetapi dengan kehati-hatian (draw conclusions when warranted but with cautions).

Menurut Emily (2011), kemampuan berpikir kritis ditunjukkan melalui indikator berikut : (1) Menganalisis argumen, klaim atau bukti (analyzing arguments, claims, or evidence); (2) Membuat kesimpulan dengan menggunakan pendekatan induktif atau deduktif (making inferences using inductive or deductive reasoning); (3) Menilai atau mengevaluasi (judging or evaluating); (4) Membuat keputusan atau solusi masalah (making decisons or solving problems). Sedangkan karakteristik atau indikator kemampuan berpikir kritis menurut Krulik dan Rudnick (1995) adalah : (1) Me meriksa, menghubungkan dan mengevaluasi semua aspek dari suatu situasi atau masalah (examining, relating, and evaluating all aspects of a situation or problem); (2) Fokus pada bagian dari suatu situasi atau masalah (focusing on parts of a situation or problem); (3) Mengumpulkan dan mengorganisasikan infor masi (gathering and organizing information); (4) Memvalidasi dan menganalisa informasi (validating and analyzing information); (5) Mengingat dan menghubungkan dengan informasi yang dipelajari sebelumnya (remem bering and associating previously learned information); (6) Menentukan kelayakan dari sebuah jawaban (determining reasonableness of an answer); (7) Menggambarkan kesimpulan yang valid (drawing valid conclusions); (8) Analisis dan reflektif dalam sifatnya (analytical and reflexive in nature).

Dari pendapat beberapa para ahli di atas, kemampuan berpikir kritis dapat dilihat melalui karakteristik atau indikator berikut : (1) Memeriksa, menghubungkan dan mengevaluasi semua aspek dari suatu situasi atau masalah (examining, relating, and evaluating all aspects of a situation or problem); (2) Fokus pada bagian dari suatu situasi atau masalah (focusing on parts of a situation or problem); (3) Mengingat dan menghubungkan dengan infor masi yang dipelajari sebelumnya (remembering and associating previously learned infor mation); (4) Menganalisis argumen, klaim atau bukti (analyzing arguments, claims, or evidence); (5) Membuat kesimpulan dengan menggunakan pendekatan induktif atau deduktif 
(making inferences using inductive or deductive reasoning).

Mengingat pentingnya kemampuan ber pikir kritis dalam kehidupan tersebut, diharap kan pembelajaran matematika dapat melatih dan mengembangkan kemampuan berpikir kritis siswa sebagaimana yang tertuang dalam GarisGaris Besar Program Pengajaran matematika. Namun pada kenyataannya, sebagian besar siswa belum menampakkan kemampuan ber pikir kritis yang baik.

Berdasarkan hasil tes diagnostik yang diberikan pada siswa (tanggal 15 Agustus 2013) di MAN 2 Model Medan didapati bahwa kemampuan berpikir kritis siswa di kelas $\mathrm{X}$ masih rendah. Data yang diperoleh menunjuk kan rata-rata persentase skor kemampuan ber pikir kritis siswa adalah $32,42 \%$ dengan kategori sangat rendah yang terdiri dari 21 siswa dalam kategori sangat rendah, 12 siswa dalam kategori rendah dan 7 siswa dalam kategori sedang. Data dari hasil observasi awal menunjukkan bahwa pembelajaran matematika yang berlangsung cenderung pasif, hanya satu atau dua siswa yang bertanya kepada guru namun tidak ada yang memberikan pendapat apabila diminta guru untuk memberikan pandangannya (saat melihat jawaban teman di depan kelas). Hal tersebut disebabkan beberapa faktor, di antaranya adalah masa adaptasi siswa dengan lingkungan sekolah baru, terdapat perbedaan pembelajaran mate matika selama di SMP dan SMA, siswa terbiasa dengan sistem belajar konvensional (teacher centered) selama di SMP, beberapa siswa kurang percaya diri karena berasal dari SMP yang kurang difavoritkan, dan terdapat beberapa siswa yang merasa bahwa ada teman sekelas mereka yang ingin menarik perhatian guru sehingga menimbulkan kecembruan di antara siswa.

Oleh karena itu, diperlukan suatu pembelajaran inovatif yang dapat mengatasi permasalah yang terjadi di kelas tersebut. Salah satu pembelajaran yang dapat digunakan adalah model pembelajaran kooperatif tipe NHT (Numbered Head Together).

Pembelajaran kooperatif dipilih karena pembelajaran kooperatif merujuk pada berbagai macam metode pengajaran di mana para siswa bekerja dalam kelompok-kelompok kecil untuk saling membantu satu sama lainnya dalam mempelajari materi pelajaran. Dalam kelas kooperatif, para siswa diharapkan dapat saling membantu, saling mendiskusikan dan bera rgumentasi, untuk mengasah pengetahuan yang mereka kuasai saat itu dan menutup kesenjangan dalam pemahaman masing-masing (Slavin, 2005:4). Adapun menurut Arends (dalam Trianto, 2010:65), kegiatan pembelajaran yang menggunakan model kooperatif memiliki ciriciri sebagai berikut: (1) siswa bekerja dalam kelompok secara kooperatif untuk menuntaskan materi belajar; (2) kelompok dibentuk dari siswa yang mempunyai kemampuan tinggi, sedang dan rendah; (3) bila memungkinkan, anggota kelompok berasal dari ras, budaya, suku, jenis kelamin yang beragam, dan (4) penghargaan lebih berorientasi kepada kelompok daripada individu.

Dari uraian tinjauan tentang pembelajaran kooperatif ini, dapat disimpulkan bahwa pem belajaran kooperatif tersebut memerlukan kerja sama antar siswa dan saling ketergantungan dalam struktur pencapaian tugas, tujuan dan penghargaan. Keberhasilan pembelajaran ini ber gantung dari keberhasilan masing-masing individu dalam kelompok, di mana keberhasilan tersebut sangat berarti untuk mencapai suatu tujuan yang positif dalam belajar kelompok.

Adapun pembelajaran kooperatif tipe NHT (Numbered Head Together) merupakan pembelajaran yang berpusat pada siswa (student centered) yang dapat menjadikan siswa aktif selama pembelajaran berlangsung. Dalam pembelajaran kooperatif tipe NHT, siswa diminta untuk bekerja dan saling berinteraksi dalam kelompok sehingga hubungan antarsiswa akan semakin baik. Selain itu, setiap siswa dalam kelompoknya masing-masing memiliki peran dan tanggung jawab yang sama sehingga rasa percaya diri siswa dapat meningkat dan setiap siswa memiliki kesempatan yang sama dalam memberikan respon terhadap guru karena setiap siswa akan dipanggil berdasarkan nomor yang telah diberikan (Slavin, 2005). Trianto (2010) berpendapat bahwa model pembelajaran kooperatif tipe NHT (Numbered Head Together) bertujuan untuk melibatkan lebih banyak siswa dalam menelaah materi yang tercakup dalam suatu pembelajaran dan mengecek pemahaman mereka terhadap isi pelajaran tersebut. Hal ini akan menarik peran aktif siswa untuk mem berikan pendapat dan argumentasi mereka mengenai pembelajaran yang diberikan. Dengan demikian, kemampuan berpikir kritis siswa akan terasah.

Dalam mengajukan pertanyaan kepada seluruh kelas, guru menggunakaan struktur 
empat tahapan NHT (Numbered Head Together) berikut : (1) Penomoran; dalam fase ini, guru membagi siswa ke dalam kelompok tiga hingga lima orang dan pada setiap kelompok diberi nomor dari 1 sampai 5; (2) Mengajukan pertanyaan; guru mengajukan sebuah per tanyaan pada siswa. Pertanyaan dapat bervariasi. Pertanyaaan diajukan secara spesifik dan dalam bentuk kalimat tanya. Misalnya, "Berapakah jumlah sisi pada bangun ruang kubus?" atau berbentuk arahan misalnya "Diharapkan setiap siswa mengetahui rumus luas dan keliling dari lima buah bangun datar"; (3) Berpikir Bersama; siswa menyatukan pendapatnya terhadap jawaban pertanyaan itu dan meyakinkan tiap anggota dalam timnya mengetahui jawaban tim; (4) Menjawab; guru memanggil suatu nomor tertentu, kemudian siswa yang nomornya sesuai mengacungkan tangannya dan mencoban untuk menjawab pertanyaan untuk seluruh kelas (Trianto, 2010).

Berdasarkan latar belakang tersebut, rumusan masalah penelitian ini yaitu apakah pembelajaran dengan model kooperatif tipe NHT (Numbered Head Together) pada dapat meningkatkan kemampuan berpikir kritis siswa kelas X MAN 2 Model Medan? Tujuan penelitiannya yaitu untuk mengetahui apakah kemampuan berpikir kritis siswa kelas X MAN 2 Model Medan dapat meningkat melalui model pembelajaran kooperatif tipe NHT (Numbered Head Together).

Hasil penelitian ini dapat dimanfaatkan sebagai berikut : (1) Bagi siswa sebagai sarana melatih kemampuan berpikir kritis siswa sehingga dapat digunakan dalam kehidupan sehari-hari dan dalam mempelajari ilmu pengetahuan yang lain; (2) Bagi guru sebagai bahan masukan dan pertimbangan untuk meningkatkan kemampuan berpikir kritis matematika siswa melalui penerapan model pembelajaran kooperatif tipe NHT (Numbered Head Together) dalam mengajar; (3) Bagi sekolah sebagai bahan pertimbangan dalam mengambil kebijakan menyetujui pembelajaran dengan menerapkan model pembelajaran kooperatif tipe NHT (Numbered Head Together) di sekolah yang bersangkutan; (4) Bagi peneliti sebagai bahan masukan untuk menambah wawasan tentang penerapan model pembelajar an kooperatif tipe NHT (Numbered Head Together) dalam menjalankan tugas sebagai pengajar kelak; (5) Sebagai bahan masukan dan perbandingan untuk penelitian berikutnya yang sejenis.

\section{METODE PENELITIAN}

Jenis penelitian ini adalah penelitian tindakan kelas (classroom action research). Subjek dalam penelitian ini adalah siswa kelas X-6 MAN 2 Model Medan tahun ajaran 2013/2014. Penelitian tindakan kelas terdiri atas beberapa siklus di mana tiap siklusnya memiliki tahapan perencanaan (planning), tindakan (acting), pengamatan (observing) dan refleksi (reflecting) yang terus berulang. Penelitian yang dilakukan ini terdiri atas dua siklus, sesuai dengan pendapat Arikunto (2006) yang menyatakan bahwa penelitian tindakan kelas harus dilakukan sekurang-kurangnya dalam dua siklus. Tindakan yang berurutan dari siklus yang terdahulu sangat menentukan bentuk siklus berikutnya. Terdapat tiga strategi yang dilakukan untuk mengumpulkan data, yaitu mengalami (experiencing), menanyakan (enquiring) dan memeriksa (examining) (Ary, 2010).

Data penelitian dikumpulkan dengan menggunakan lembar pengamatan guru dan siswa dan tes kemampuan berpikir kritis di akhir siklus (Sugiyono, 2013). Lembar pengamatan guru dan siswa digunakan untuk melihat apakah pembelajaran matematika yang dilakukan telah sesuai perencanaan penerapan pembelajaran kooperatif tipe NHT (Numbered Head Together). Pemberian tes di akhir siklus dilakukan untuk melihat apakah ada peningkatan kemampuan berpikir kritis setelah menerapkan pembelajaran kooperatif tipe NHT (Numbered Head Together) di dalam kelas.

Prosedur penelitian tindakan kelas ini terdiri dari beberapa tahapan yang terus berulang membentuk siklus sesuai dengan permasalahan yang ingin dipecahkan. Apabila permasalahan belum dapat dipecahkan, maka penelitian dilanjutkan ke siklus II dan seterusnya. Berikut ini adalah tahap-tahap penelitian tindakan kelas untuk setiap siklusnya.

\section{Siklus I}

a. Permasalahan

Permasalahan pada awal siklus I diperoleh dari hasil tes diagnostic yang menunjukkan kemampuan berpikir kritis matematika yang rendah. Faktor yang menjadi penyebabnya adalah metode pengajaran yang digunakan masih monoton dan tidak adanya 
penggunaan media pembelajaran yang sesuai. Berdasarkan permasalahan tersebut, disusunlah suatu perencanaan untuk mengatasinya.

b. Perencanaan Tindakan Siklus I

1. Membuat skenario pembelajaran yang berisikan langkah-langkah kegiatan dalam pembelajaran model kooperatif tipe NHT Numbered Head Together).

2. Mempersiapkan sarana pendukung pembelajaran yang mendukung pelaksanaan tindakan, yaitu buku ajar untuk siswa, buku untuk peneliti yang berisi skenario pembelajaran dan media pembelajaran seperti power point dan LKS.

3. Mempersiapkan instrumen penelitian, yaitu lembar observasi untuk mengamati kegiatan belajar mengajar (lembar observasi aktivitas guru dan siswa) dan post test I.

c. Pelaksanaan Tindakan Siklus I

Pada tahap ini, peneliti berperan sebagai guru untuk melakukan tindakan dalam proses pembelajaran yaitu :

1. Menyampaikan tujuan pembelajaran yang ingin dicapai dan memotivasi siswa serta memberikan apersepsi agar siswa mengingat kembali tentang bentuk pangkat.

2. Menyajikan informasi kepada siswa mengenai logaritma dan sifat-sifat logaritma.

3. Membagi siswa menjadi beberapa kelompok yang terdiri dari 3-5 siswa secara heterogen dan memberi nomor pada tiap anggota kelompok dari 1 - 5 .

4. Membagikan LKS dan menjelaskan cara pengerjaan LKS kepada siswa.

5. Membimbing kelompok-kelompok belajar siswa yang sedang berdiskusi dan memastikan bahwa anggota setiap kelompok ikut berdiskusi dan memahami jawaban dari pertanyaan yang diberikan.

6. Mengevaluasi hasil diskusi dengan memanggil suatu nomor tertentu, kemudian siswa yang nomornya sesuai menjawab pertanyaan.

7. Memberikan latihan kepada siswa

8. Siswa mengerjakan soal latihan, kemudian memberikan kesempatan kepada siswa untuk melakukan tanya jawab terhadap penyelesaian soal-soal yang siswa kerjakan untuk menemukan penyelesaian yang benar.
9. Menyimpulkan materi bersama dengan siswa.

10.Di akhir pelaksanaan siklus I, siswa diberikan post test I yang bertujuan untuk melihat tingkat kemampuan berpikir kritis siswa.

d. Pengamatan Siklus I

Tahap pengamatan/observasi dilakukan bersamaan pada saat tindakan dilakukan. Peneliti bertindak sebagai guru sedangkan guru matematika MAN 2 Model Medan sebagai pengamat (observer) yang mengamati proses belajar mengajar yang dilakukan. Observasi dilakukan dengan berpedoman pada lembar observasi.

e. Analisis Data Siklus I

Pada tahap ini peneliti menyeleksi seluruh data yang diperoleh dari hasil post test I kemudian dianalisis melalui beberapa tahap yaitu: reduksi data, paparan data, verifikasi dan kemudian penarikan kesimpulan.

f. Refleksi Siklus I

Pada tahap ini, peneliti melakukan kegiatan perenungan untuk mengkaji secara menyeluruh tindakan yang telah dilakukan berdasarkan data-data yang diperoleh dari instrumen penelitian. Pada kegiatan ini, didapati permasalahan apa yang masih timbul di siklus I, apa penyebabnya dan bagaimana mengatasi permasalahan tersebut. Hasil refleksi ini menjadi acuan untuk memberikan tindakan-tindakan apa yang diperlukan untuk mengatasi permasalahan tersebut di siklus II.

\section{Siklus II}

a. Permasalahan

Dalam siklus II ini permasalahan belum dapat diidentifikasikan secara jelas karena data hasil pelaksanaan siklus I belum diperoleh. Adapun rancangan tindakan di siklus II merupakan hasil refleksi dari siklus I dengan penambahan tindakan yang diperlukan untuk mengatasi permasalah yang timbul selama siklus I sehingga pembelajaran di siklus II dapat berlangsung lebih baik.

b. Perencanaan Tindakan Siklus II

1. Membuat skenario pembelajaran yang berisikan langkah-langkah kegiatan dalam pembelajaran model kooperatif tipe NHT Numbered Head Together).

2. Mempersiapkan sarana pendukung pembelajaran yang mendukung pelaksanaan tindakan, yaitu buku ajar 
untuk siswa, buku untuk peneliti yang berisi skenario pembelajaran dan media pembelajaran seperti power point dan LKS.

3. Mempersiapkan instrumen penelitian, yaitu lembar observasi untuk mengamati kegiatan belajar mengajar (lembar observasi aktivitas guru dan siswa) dan post test II.

c. Pelaksanaan Tindakan Siklus II

Pada tahap ini, peneliti berperan sebagai guru untuk melakukan tindakan dalam proses pembelajaran. Kegiatan pembelajaran yang dilakukan, yaitu:

1. Menyampaikan tujuan pembelajaran yang ingin dicapai dan memotivasi siswa serta memberikan apersepsi agar siswa mengingat kembali tentang bilangan berpangkat.

2. Menyajikan informasi kepada siswa mengenai menyederhanakan bentuk logaritma dan menentukan nilai logaritma.

3. Membagi siswa menjadi beberapa kelompok yang terdiri dari 3-5 siswa secara heterogen dan memberi nomor pada tiap anggota kelompok dari 1 - 5 .

4. Membagikan LKS dan menjelaskan cara pengerjaan LKS kepada siswa.

5. Membimbing kelompok-kelompok belajar siswa yang sedang berdiskusi dan memastikan bahwa anggota setiap kelompok ikut berdiskusi dan memahami jawaban dari pertanyaan yang diberikan.

6. Mengevaluasi hasil diskusi dengan memanggil suatu nomor tertentu, kemudian siswa yang nomornya sesuai menjawab pertanyaan.

7. Memberikan latihan kepada siswa

8. Siswa mengerjakan soal latihan, kemudian memberikan kesempatan kepada siswa untuk melakukan tanya jawab terhadap penyelesaian soal-soal yang siswa kerjakan untuk menemukan penyelesaian yang benar.

9. Menyimpulkan materi bersama dengan siswa.

10.Di akhir pelaksanaan siklus II, siswa diberikan post test II yang bertujuan untuk melihat tingkat kemampuan berpikir kritis siswa.

d. Pengamatan Siklus II

Tahap pengamatan/observasi dilakukan bersamaan pada saat tindakan dilakukan. Dalam hal ini peneliti bertindak sebagai guru sedangkan guru matematika MAN 2 Model Medan sebagai pengamat (observer) yang mengamati proses belajar mengajar yang dilakukan. Observasi dilakukan dengan berpedoman pada lembar observasi.

e. Analisis Data Siklus II

Pada tahap ini peneliti menyeleksi seluruh data yang diperoleh dari hasil post test II kemudian dianalisis melalui beberapa tahap yaitu: reduksi data, paparan data, verifikasi dan kemudian penarikan kesimpulan.

f. Refleksi Siklus II

Pada tahap ini, peneliti melakukan kegiatan perenungan untuk mengkaji secara menyeluruh tindakan yang telah dilakukan berdasarkan data-data yang diperoleh dari instrumen penelitian. Hasil data tersebut, kemudian digunakan sebagai dasar pengambilan kesimpulan, apakah kegiatan yang dilakukan telah meningkatkan kemampuan berpikir kritis siswa? Setelah siklus II ini, peneliti menghentikan penelitiannya.

Data yang diperoleh pada tiap siklus digunakan sebagai bahan refleksi mengenai pembelajaran yang telah dilakukan dan akan digunakan sebagai pedoman untuk perencanaan pada siklus selanjutnya. Data dianalisa dengan indikator keberhasilan kualitatif secara deskriptif di mana tiap siswa memperoleh hasil belajar minimal $65 \%$ atau dalam kategori tuntas.

\section{HASIL DAN PEMBAHASAN}

\section{Pra Siklus I}

Hasil tes diagnostik menunjukkan bahwa siswa memiliki kemampuan berpikir kritis yang sangat rendah, yaitu dengan rata-rata persentase skor kemampuan berpikir kritis sebesar 32,42\%. Terdapat 21 siswa dengan kemampuan berpikir kritis yang sangat rendah, 12 siswa pada kategori rendah dan 7 siswa pada kategori sedang. Hal tersebut ditunjukkan tabel berikut :

Tabel 1. Persentase Skor Kemampuan Berpikir Siswa Hasil Tes Pra Siklus I

\begin{tabular}{|c|c|c|c|}
\hline $\begin{array}{c}\text { Persentase } \\
\text { Skor }\end{array}$ & Kategori & Frekuensi & $\begin{array}{c}\text { Persentase } \\
\text { Kelas }\end{array}$ \\
\hline $\begin{array}{c}55 \%<\mathrm{KBK} \leq \\
70 \%\end{array}$ & Sedang & 7 & $17,5 \%$ \\
\hline $\begin{array}{c}40 \%<\mathrm{KBK} \leq \\
55 \%\end{array}$ & Rendah & 12 & $30 \%$ \\
\hline $\mathrm{KBK}<40 \%$ & $\begin{array}{c}\text { Sangat } \\
\text { Rendah }\end{array}$ & 21 & $52,5 \%$ \\
\hline
\end{tabular}

Keterangan : 
KBK : Kemampuan Berpikir Kritis Siklus I

Analisa data lembar observasi dari pelaksanaan siklus I menunjukkan bahwa penerapan pembelajaran kooperatif tipe NHT di kelas masih belum maksimal (dalam kategori cukup). Hal ini terlihat pada indikator perencanaan dan pelaksanaan yang mendapat skor 2 dari skor maksimal 4. Aktivitas siswa pun masih belum baik karena pada lembar observasi emperoleh skor 2 dari skor maksimal 4.

Analisa tes siklus I menunjukkan bahwa rata-rata persentase skor kemampuan berpikir siswa meningkat dari $32,43 \%$ (sebelum siklus I) menjadi $49,13 \%$ pada siklus I. Terdapat 1 siswa yang memiliki kemampuan berpikir kritis dengan kategori sangat tinggi, 9 siswa dengan kategori tinggi, 16 siswa dengan kategori sedang dan 14 siswa dengan kategori rendah. Namun, rata-rata persentase skor siswa tersebut masih dalam kategori rendah. Selain itu, siswa yang mendapat nilai lebih besar atau sama dengan 65 (memenuhi syarat ketuntasan materi) sebanyak 28 siswa atau sebesar $70 \%$ sedangkan siswa yang belum tuntas sebanyak 12 siswa atau sebesar 30\%. Data ditunjukkan oleh tabel berikut :

Tabel 2. Persentase Skor Kemampuan Berpikir Siswa Hasil Tes Siklus I

\begin{tabular}{|c|c|c|c|}
\hline Persentase Skor & Kategori & Frekuensi & $\begin{array}{c}\text { Persentase } \\
\text { Kelas }\end{array}$ \\
\hline $\begin{array}{c}85 \%<\mathrm{KBK} \leq \\
100 \%\end{array}$ & $\begin{array}{c}\text { Sangat } \\
\text { Tinggi }\end{array}$ & 1 & $2,5 \%$ \\
\hline $\begin{array}{c}70 \%<\mathrm{KBK} \leq \\
85 \%\end{array}$ & Tinggi & 9 & $22.5 \%$ \\
\hline $\begin{array}{c}55 \%<\mathrm{KBK} \leq \\
70 \%\end{array}$ & Sedang & 16 & $40 \%$ \\
\hline $\begin{array}{c}40 \%<\mathrm{KBK} \leq \\
55 \%\end{array}$ & Rendah & 14 & $35 \%$ \\
\hline
\end{tabular}

Hasil analisa siklus I memperlihatkan bahwa pembelajaran kooperatif tipe NHT masih belum baik dan tingkat kemampuan berpikir kritis siswa masih dalam kategori rendah. Persentase ketuntasan kelas yang diperoleh sebesar $70 \%$ masih belum memenuhi syarat katuntasan klasikal (sebesar 85\%).

Berdasarkan refleksi siklus I, masih terdapat beberapa masalah yang terjadi di siklus I, yaitu (1) tidak semua anggota kelompok aktif dalam diskusi kelompoknya karena mereka tidak memperoleh lembar kerja siswa; (2) tidak semua anggota kelompok memahami hasil diskusi kelompok mereka sendiri; (3) pelaksanaan pembelajaran oleh peneliti tidak sesuai dengan waktu yang direncanakan.

Oleh karena berbagai kekurangan yang masih terjadi di siklus I, maka penelitian dilanjutkan di siklus II dengan memberikan beberapa perbaikan, seperti : (1) memberikan lembar kerja kepada masing-masing anggota kelompok; (2) peneliti lebih memberikan perhatian kepada siswa yang memiliki skor rendah di masing-masing kelompok; (3) bertanya atau meminta respon kepada siswa yang memiliki skor rendah di masing-masing kelompok; (4) memberikan penghargaan kepada kelompok apabila anggotanya dapat memberikan respon sesuai dengan yang diharapkan peneliti; (5) memberikan hukuman kepada kelompok apabila anggotanya tidak dapat memberikan respon sesuai dengan yang diharapkan peneliti; (6) peneliti lebih memperhatikan alokasi waktu sesuai dengan perencanaan pembelajaran.

\section{Siklus II}

Analisa data lembar observasi dari pelaksanaan siklus II menunjukkan bahwa penerapan pembelajaran kooperatif tipe NHT di kelas dalam kategori baik. Hal ini terlihat pada indikator perencanaan dan pelaksanaan yang mendapat skor 3,14 dari skor maksimal 4 . Aktivitas siswa sudah dalam kategori baik dengan skor sebesar 3,1875 dari skor maksimal 4.

Analisa tes siklus II menunjukkan bahwa rata-rata persentase skor kemampuan berpikir siswa meningkat dari $49,13 \%$ (siklus I) menjadi $55,625 \%$ pada siklus II. Terdapat 3 siswa yang memiliki kemampuan berpikir kritis dengan kategori sangat tinggi, 14 siswa dengan kategori tinggi, 17 siswa dengan kategori sedang dan 6 siswa dengan kategori rendah. Rata-rata persentase skor siswa berada dalam kategori sedang dan siswa yang mendapat nilai lebih besar atau sama dengan 65 (memenuhi syarat ketuntasan materi) sebanyak 35 siswa atau sebesar $87,5 \%$ sedangkan siswa yang belum tuntas sebanyak 5 siswa atau sebesar $12,5 \%$. Data ditunjukkan oleh tabel berikut :

Tabel 3. Persentase Skor Kemampuan Berpikir Siswa Hasil Tes Siklus II

\begin{tabular}{l|c|c|c|} 
Persentase & Kategori & Frekuensi & Persentase \\
\hline
\end{tabular} 


\begin{tabular}{|c|c|c|c|}
\hline Skor & & & kelas \\
\hline $\begin{array}{c}85 \%<\mathrm{KBK} \leq \\
100 \%\end{array}$ & $\begin{array}{c}\text { Sangat } \\
\text { Tinggi }\end{array}$ & 3 & $7,5 \%$ \\
\hline $\begin{array}{c}70 \%<\mathrm{KBK} \leq \\
85 \%\end{array}$ & Tinggi & 14 & $35 \%$ \\
\hline $\begin{array}{c}55 \%<\mathrm{KBK} \leq \\
70 \%\end{array}$ & Sedang & 17 & $42,5 \%$ \\
\hline $\begin{array}{c}40 \%<\mathrm{KBK} \leq \\
55 \%\end{array}$ & Rendah & 6 & $15 \%$ \\
\hline
\end{tabular}

Hasil analisa siklus II memperlihatkan bahwa pelaksanaan pembelajaran kooperatif tipe NHT sudah dalam kategori baik dan tingkat kemampuan berpikir kritis siswa berada dalam kategori rendah. Persentase ketuntasan kelas yang diperoleh sebesar $87,5 \%$ dan sudah memenuhi syarat katuntasan klasikal (sebesar $85 \%$ ). Berdasarkan hal tersebut, penelitian sudah menjadi tujuannya sehingga tidak dilanjutkan ke siklus berikutnya.

Data dari pretest (sebelum siklus I), post test I (siklus I0 dan post test II (siklus II) menunjukkan peningkatan rata-rata skor kemampuan berpikir siswa dari 32,42\% (kategori rendah) sebelum siklus I, menjadi 49,13\% (kategori rendah) pada siklus I dan $55,63 \%$ (kategori sedang) pada sikus II. Sedangkan tingkat ketuntasan klasikal meningkat dari $70 \%$ pada siklus I menjadi $87,5 \%$ pada siklus II. Berikut adalah diagram batang yang menunjukkan peningkatan kemapuan berpikir kritis siswa.

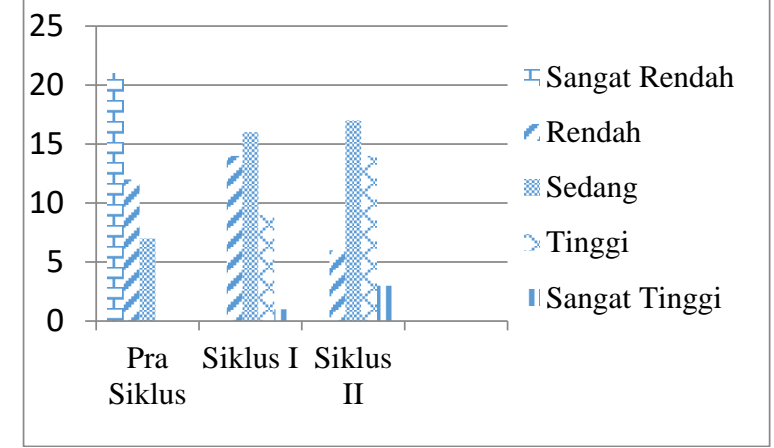

Gambar 1. Diagram Batang Kemampuan Berpikir Kritis Siswa Dari Hasil Tes Pra Siklus, Siklus I dan Siklus II

\section{KESIMPULAN}

Berdasarkan analisa data diperoleh bahwa penerapan pembelajaran kooperatif tipe NHT (Numbered Head Together) dapat meningkatkan kemampuan berpikir kritis siswa kelas X MAN 2 Model Medan tahun ajaran 2013/2014. Hal tersebut terlihat dari hasil tes siswa, baik yang dilakukan sebelum siklus I (pra siklus), setelah siklus I dan setelah siklus II. Penerapan pembelajaran ini juga dapat meningkatkan aktivitas siswa dalam pembelajaran di kelas.

\section{DAFTAR PUSTAKA}

Arikunto, S. \& Suhardjono. (2006). Penelitian Tindakan Kelas. Bumi Aksara, Jakarta.

Ary, D., Jacobs, L. C., \& Sorensen, C. (2010). Introduction to Research in Education, $8^{\text {th }}$ ed. California, Wadsworth.

Departemen Pendidikan Nasional. (2008). Undang-Undang Republik Indonesia Nomor 20 Tahun 2003. Depdiknas.

Eggen \& Kauchak. (2012). Strategi dan Model Pembelajaran. Indeks, Jakarta.

Emily, R. L. (2011). Critical Thinking: A Literature Review. Pearson.

Ennis, R. H. (1993). Critical Thinking Assessment. The Ohio State University.

Hudojo, H. (1988). Mengajar Belajar Matematika. Depdikbud.

Krulick \& Rednick. (1995). Assessing Critical Thinking Skills. University Park Press.

Santrack, W. J. (2008). Psikologi Pendidikan, Kencana, Jakarta.

Slavin, R. (2011). Cooperatif Learning, Teori, Riset dan Praktik. Nusa Media, Jakarta.

Sugiyono. (2013). Metode Penelitian Pendidikan. Alfabeta, Bandung.

Suherman, E., dkk. (2001). Strategi Pembelajaran Matematika Kontemporer. JICA UPI, Bandung.

Trianto. (2010). Mendesain Model Pembelajaran Inovatif-Progresif. Kencana, Jakarta. 